\title{
Observation of Intact and Proteolytically Cleaved Amyloid-Beta (1-40)-Oleuropein Noncovalent Complex at Neutral pH by Mass Spectrometry
}

\author{
Ioana Cezara Caba ${ }^{1,2}$, Raluca Ştefănescu ${ }^{1, *(\mathbb{D})}$ and Bogdan Ionel Tamba ${ }^{1,3}$ (D) \\ 1 Center for Advanced Research and Development in Experimental Medicine (CEMEX), "Grigore T. Popa" \\ University of Medicine and Pharmacy, 16 Universitatii Street, 700115 Iasi, Romania; \\ ioana-cezara.caba@umfiasi.ro (I.C.C.); bogdan.tamba@umfiasi.ro (B.I.T.) \\ 2 Department of Toxicology, Faculty of Pharmacy, "Grigore T. Popa" University of Medicine and Pharmacy, \\ 16 Universitatii Street, 700115 Iasi, Romania \\ 3 Department of Pharmacology, Clinical Pharmacology and Algesiology, "Grigore T. Popa" University of \\ Medicine and Pharmacy, 16 Universitatii Street, 700115 Iasi, Romania \\ * Correspondence: raluca.stefanescu@umfiasi.ro
}

check for updates

Citation: Caba, I.C.; Ştefănescu, R.; Tamba, B.I. Observation of Intact and Proteolytically Cleaved Amyloid-Beta (1-40)-Oleuropein Noncovalent Complex at Neutral $\mathrm{pH}$ by Mass Spectrometry. Molecules 2021, 26, 3261. https://doi.org/10.3390/

molecules26113261

Academic Editors: Elisa Ovidi and Antonio Tiezzi

Received: 4 May 2021

Accepted: 25 May 2021

Published: 28 May 2021

Publisher's Note: MDPI stays neutral with regard to jurisdictional claims in published maps and institutional affiliations.

Copyright: (c) 2021 by the authors. Licensee MDPI, Basel, Switzerland. This article is an open access article distributed under the terms and conditions of the Creative Commons Attribution (CC BY) license (https:// creativecommons.org/licenses/by/ $4.0 /)$.
Abstract: Mass spectrometry analyses carried out on mass spectrometers equipped with soft ionization sources demonstrated their utility in the assessment of the formation of noncovalent complexes and the localization of the binding sites. Direct analyses by mass spectrometry of the noncovalent complex formed in acidic and mildly acidic environments by amyloid beta (1-40) peptide and oleuropein have been previously described, and, in several studies, the absorption, metabolism, excretion, and the implications in the prevention and therapy of Alzheimer's disease of oleuropein have been investigated. Our paper presents modifications of the method previously employed for noncovalent complex observation, namely, the amyloid beta (1-40) pretreatment, followed by an increase in the $\mathrm{pH}$ and replacement of the chemical environment from ammonium acetate to ammonium bicarbonate. The formation of noncovalent complexes with one or two molecules of oleuropein was detected in all chemical solutions used, and the amyloid beta (17-28) binding site was identified via proteolytic experiments using trypsin prior to and after noncovalent complex formation. Our results highlight the importance of further studies on the effect of oleuropein against amyloid beta aggregation.

Keywords: Alzheimer's disease; beta-amyloid peptide; oleuropein; mass spectrometry; noncovalent complex; electrospray ionization; triple quadrupole

\section{Introduction}

The study of noncovalent complexes, and particularly the identification of molecules' binding regions, is essential for biomedical studies, as it allows for the investigation of the interaction of different molecules in living organisms and the effects exerted by foreign molecules to which living organisms are exposed. Examples of such interactions are antigens-antibodies and receptors-ligands.

Mass spectrometry methods developed for noncovalent complex analysis are valuable tools for assessing, directly or indirectly, whether the tested substances interact. Direct analysis by mass spectrometry of complexes formed in a solution is possible by using a chemical medium similar to those found in the human physiology and ensuring the mass spectrometric compatibility of the chemical solutions containing the molecules whose interactions are studied. Both electrospray ionization (ESI) and matrix assisted laser desorption and ionization (MALDI) were proven to be effective ionization methods for the analysis of noncovalent complexes and of compounds belonging to different classes of molecules; however, studies aimed at analyzing noncovalent complexes at neutral $\mathrm{pH}$ using MALDI are less frequent [1,2]. The indirect methods involve the mass spectrometric identification of a compound exposed to an affinity medium containing the immobilized 
cognate biomolecule and eluted using a dissociating solution that is compatible with electrospray ionization (ESI) or matrix assisted laser desorption and ionization (MALDI). The latter approach allows the selection of a chemical medium which contains inorganic ions and biomolecules resembling the body chemical environment in which the interaction takes place.

Alzheimer's disease (AD) is an uncurable neurodegenerative illness. According to the amyloid cascade hypothesis, abnormal extracellular accumulation of aggregated amyloid beta peptides in the brain leads to neurotoxicity and cognitive decline.

Amyloid beta $(A \beta)$ peptides are naturally occurring amino acid chains produced from an amyloid precursor protein (APP) by a cleavage pathway involving two proteases: beta- and gamma-secretase. The resulting peptides, denoted as $A \beta(1-40)$ and $A \beta(1-42)$, contain mainly 40 or 42 amino acids and represent the amyloid precursor protein fragments $\mathrm{APP}(672-711)$ and $\mathrm{APP}(672-713)$, respectively. Amino-terminal truncated peptides were also reported. The role of amyloid beta in the human body is not yet completely understood. It was proven that the ratio of $A \beta(1-40)$ to $A \beta(1-42)$ is lower in patients with inherited Alzheimer's disease forms in comparison to healthy individuals [3].

Passive and active immunotherapeutic approaches targeting the clearance of amyloid beta peptides from body fluids have been investigated in recent years. Mass spectrometry, affinity chromatography, and proteolytic cleavage have been proven to be effective methods for epitope elucidation. Epitope excision and extraction of the amino acid sequence from amyloid beta peptides recognized by the amyloid beta specific antibodies were employed in several studies. Similar studies were carried out for the identification of the amyloid precursor protein epitope of an antibody directed towards the carboxyl-terminal end of the amyloid precursor protein. Furthermore, mass spectrometry methods for the identification of paratopes and complete antibody sequencing of human autoantibodies recognizing beta amyloid peptide were developed [4,5].

Considering that one of the current approaches for preventing Alzheimer's disease aims to identify the aggregation inhibitor of an amyloid beta peptide, the current paper investigates the interaction, at neutral $\mathrm{pH}$, between the $\mathrm{A} \beta(1-40)$ peptide and the glycosylated secoiridoid oleuropein, a secondary metabolite present in high amounts in olive tree leaves (Olea europaea) [6]. The observation method of the noncovalent complex at pH 3.0 was previously developed by Bazoti et al. [7]. The authors found two molecules of oleuropein binding to one molecule of $A \beta(1-40)$ and investigated the binding sequence interacting with oleuropein by proteolytic cleavage prior to, or after, the addition of oleuropein, followed by direct analysis of the resulting peptide mixture. The results showed that the sequence of $A \beta(17-28)$ represents one of the sequences of amyloid beta peptide involved in the binding to oleuropein [8]. Compared with previous published studies, our paper introduces the following methodology changes: a) a modified method for the pretreatment and solubilization of amyloid beta peptide (1-40) and b) the analysis of the noncovalent complex and identification of the binding sequence at different $\mathrm{pH}$ values, including neutral $\mathrm{pH}$ (7.35).

\section{Results and Discussions}

\subsection{Preparation of Beta-Amyloid (1-40) and Oleuropein Stock Solutions}

Beta-amyloid (1-40) was solubilized in 1,1,1,3,3,3-hexafluoroisopropanol at $1 \mathrm{mg} / \mathrm{mL}$ concentration, according to Yoshiike et al. [9], with incubation for $2 \mathrm{~h}$, at room temperature, to preserve the monomeric form of the peptide. Considering the effect of fluorinated alcohol in inducing alpha-helical conformation at peptides and proteins, the peptide $A \beta(1-40)$ was allowed to dry prior to the addition of the solvent and oleuropein for the investigation of noncovalent complex formation.

Based on the study published by Yateem et al. [10], oleuropein was solubilized in $20 \%$ acetonitrile and $80 \%$ double-distilled water. 


\subsection{Complex Formation at $\mathrm{pH} 3$}

The mass spectrum of the equimolar mixture of $A \beta(1-40)$ peptide and oleuropein prepared in $0.5 \mathrm{mM}$ ammonium acetate containing $0.25 \%$ acetic acid, $\mathrm{pH} 3$, is shown in Figure 1. The signals at $m / z 1444.57,1083.58,866.98,722.69$, and 619.59 were assigned to the molecular ions of the $\mathrm{A} \beta(1-40)$ molecules protonated with $3,4,5,6$, and 7 protons, respectively. The signal at $m / z 563.39$ was assigned to the sodium adduct of oleuropein $[\mathrm{OLE}+\mathrm{Na}]^{+}$. The peaks observed at $m / z 1218.78,975.18$, and 812.78 were assigned to the complexes between one molecule of $A \beta(1-40)$ and one molecule of oleuropein protonated with four, five and six protons, respectively. The peak observed at $m / z 1353.58$ was assigned to the quadruple-protonated molecular ion of the complex formed between $A \beta(1-40)$ and two molecules of oleuropein. The signal at $\mathrm{m} / \mathrm{z} 1624.47$ was assigned to the complex between $A \beta(1-40)$ and one molecule of oleuropein protonated with three protons and was observed by examining the $m / z$ range 1500-2000 (result not shown in the Figure 1 ) and, at $m / z$ 1804.57, the triple-protonated molecular ion of $A \beta(1-40)$ forming a complex with two molecules of oleuropein was observed.

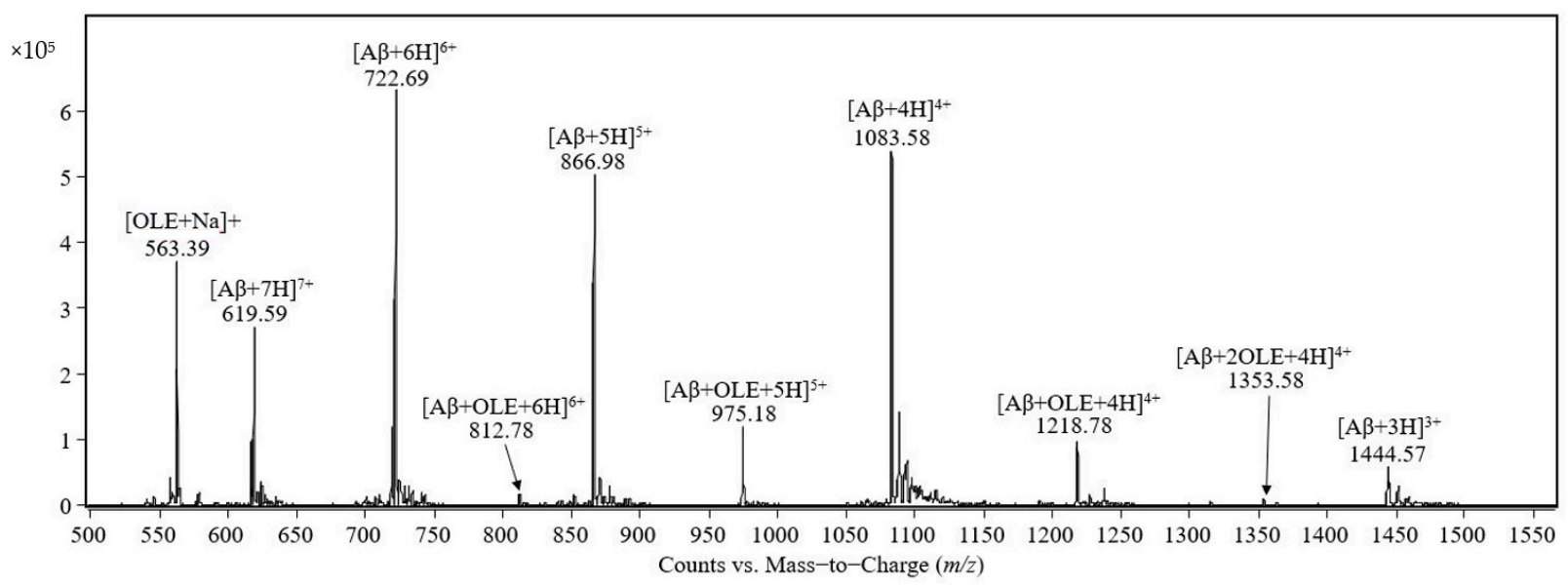

Figure 1. Mass spectrum of the 1:1 complex formed between $\mathrm{A} \beta(1-40)$ and oleuropein both at $50 \mathrm{pmol} / \mu \mathrm{L}$ in a final solution of $0.5 \mathrm{mM}$ ammonium acetate and $0.25 \%$ acetic acid, $\mathrm{pH} 3$, recorded $30 \mathrm{~min}$ after incubation on the electrospray-triple quadrupole mass spectrometer.

\subsection{Complex Formation in Ammonium Acetate at Different $p H$ Values}

The analysis by electrospray-triple quadrupole of four solutions containing $50 \mathrm{pmol} / \mu \mathrm{L}$ $\mathrm{A} \beta(1-40)$ solubilized in ammonium acetate $0.5 \mathrm{mM}$ at $\mathrm{pH}$ values of $4.4,5.3,6.2$, and 7.4 indicates that all four mass spectra signals are present at $m / z 1083.48,866.98,722.69$, and 619.59 corresponding to $A \beta(1-40)$ molecules possessing $4,5,6$ and 7 positive charges, respectively, denoted as $[\mathrm{A} \beta+4 \mathrm{H}]^{4+},[\mathrm{A} \beta+5 \mathrm{H}]^{5+},[\mathrm{A} \beta+6 \mathrm{H}]^{6+},[\mathrm{A} \beta+7 \mathrm{H}]^{7+}$. In the next step, mass spectra were acquired for the solutions containing $50 \mathrm{pmol} / \mu \mathrm{L} A \beta(1-40)$ and $100 \mathrm{pmol} / \mu \mathrm{L}$ oleuropein solubilized in $0.47 \mathrm{mM}$ ammonium acetate at four $\mathrm{pH}$ values (4.4, $5.3,6.2,7.4)$. In all four mass spectra, at the $m / z$ values $1083.48,866.98,722.69$, and 619.59, there are signals corresponding to molecules of $A \beta(1-40)$ carrying $4,5,6$, and 7 protons. The signal at $\mathrm{m} / \mathrm{z} 563.39$ corresponds to the adduct with sodium of one molecule of oleuropein (denoted as [OLE $+\mathrm{Na}]^{1+}$ ) and the signals observed at $m / z 975.18$ and 1218.68 correspond to the noncovalent complexes formed between one molecule of $A \beta(1-40)$ and one molecule of oleuropein carrying 5 and 4 protons, respectively $\left([\mathrm{A} \beta+\mathrm{OLE}+5 \mathrm{H}]^{5+},[\mathrm{A} \beta+\mathrm{OLE}+\right.$ $4 \mathrm{H}]^{4+}$ ). A similar result was obtained for the samples incubated for $2 \mathrm{~h}$ at $25^{\circ} \mathrm{C}$.

The mass spectrum obtained after the analysis of the equimolar solution containing $\mathrm{A} \beta(1-40)$ and oleuropein at the concentration of $50 \mathrm{pmol} / \mu \mathrm{L}$ in $0.47 \mathrm{mM}$ ammonium acetate, $\mathrm{pH}$ 7.4, is shown in Figure 2. The peaks observed in the mass spectrum were identified as follows: (i) the peaks at $m / z 563.39$ and 579.39 correspond to the adducts with sodium and potassium, respectively, denoted as $[\mathrm{OLE}+\mathrm{Na}]^{1+}$ and $[\mathrm{OLE}+\mathrm{K}]^{1+}$; (ii) the 
peaks at $m / z 1444.57,1083.48,866.98,722.69$ and 619.59 correspond to $\mathrm{A} \beta(1-40)$ molecules carrying $3,4,5,6$, and 7 positive charges, respectively; (iii) the peaks at $m / z 1218.58,975.18$, and 812.48 correspond to the noncovalent complex formed by one molecule of $\mathrm{A} \beta(1-40)$ and one molecule of oleuropein protonated with 4,5 , and 6 protons, respectively.

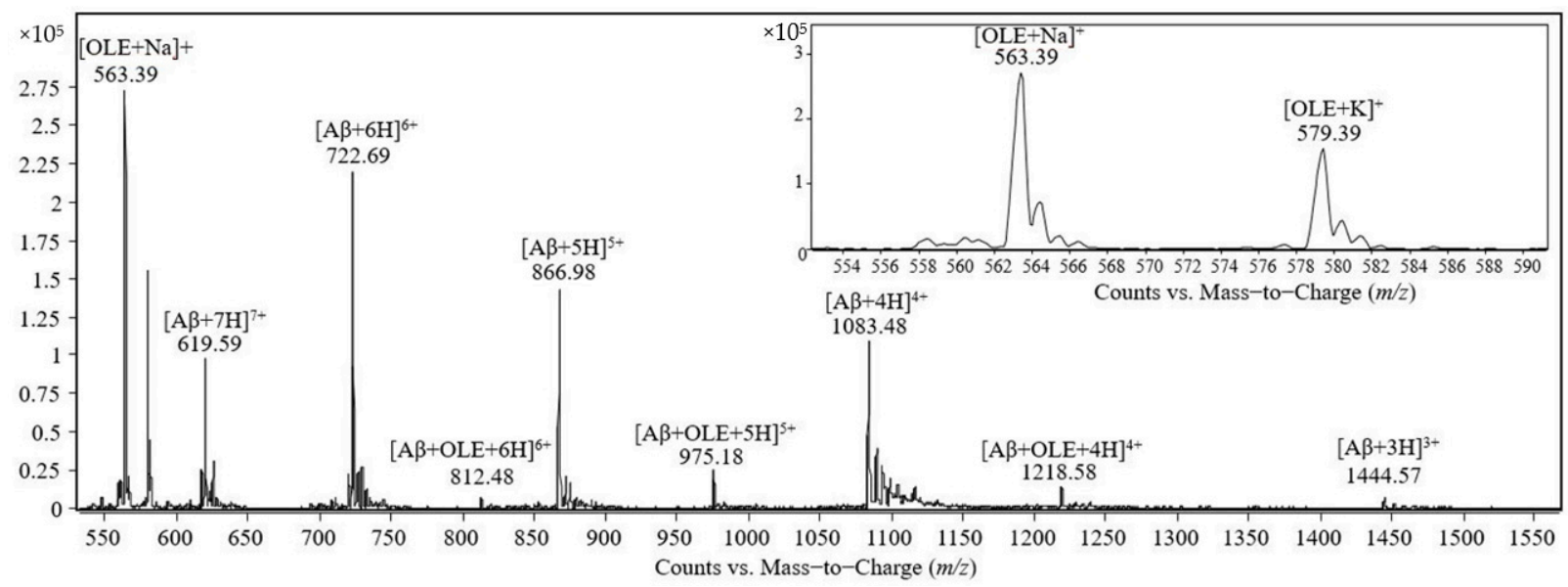

Figure 2. Mass spectrum obtained by ESI-triple quadrupole analysis of the equimolar solution containing A $\beta(1-40)$ and oleuropein at $50 \mathrm{pmol} / \mu \mathrm{L}$ in $0.47 \mathrm{mM}$ ammonium acetate, $\mathrm{pH} 7.4$, after incubation for $30 \mathrm{~min}$ at room temperature.

\subsection{Complex Formation in Ammonium Bicarbonate at Neutral pH}

The mass spectrum acquired during the analysis at ESI-triple quadrupole of the solution containing equimolar amounts of $A \beta(1-40)$ and oleuropein at the concentration of $50 \mathrm{pmol} / \mu \mathrm{L}$, incubated for $30 \mathrm{~min}$ at $37{ }^{\circ} \mathrm{C}$, is presented in the Figure 3 . A second analysis was performed for the same sample, which was agitated at $37^{\circ} \mathrm{C}$ for $2 \mathrm{~h}$ and a mass spectrum was recorded. The mass spectrum presented in the Figure 3 contains the same signals as described above for Figure 2.

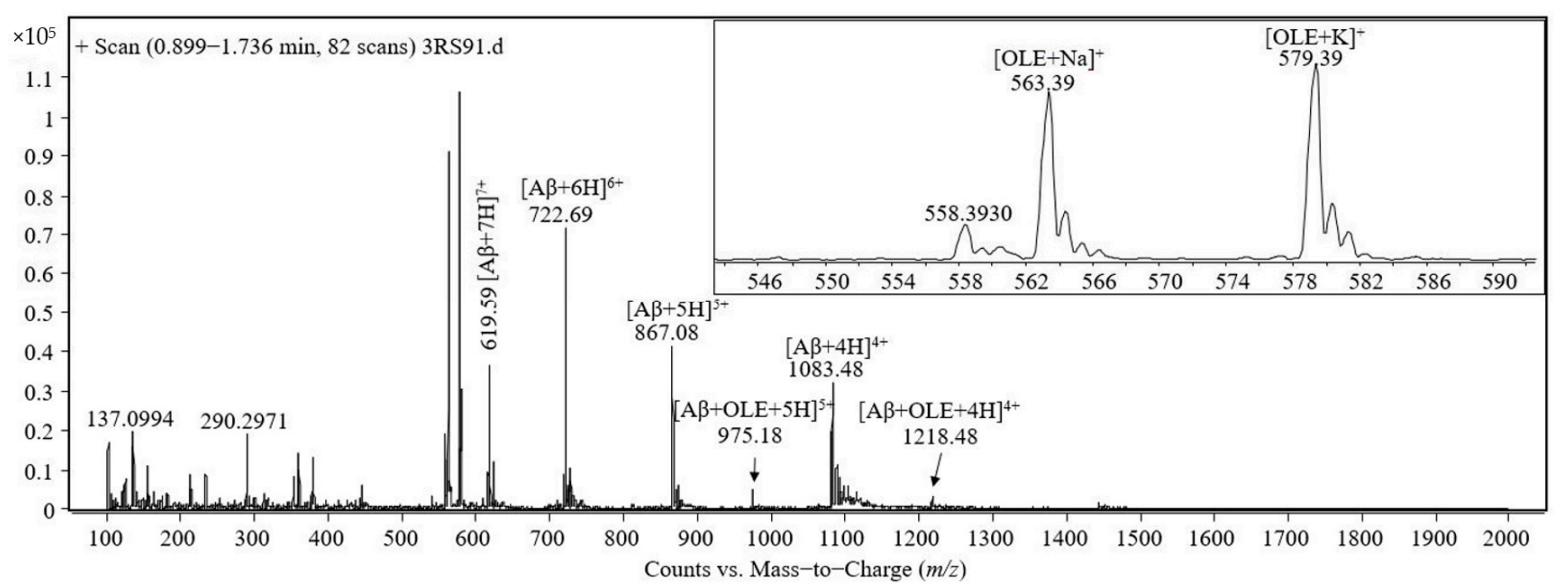

Figure 3. Mass spectrum obtained by ESI-triple quadrupole analysis of the equimolar solution containing $50 \mathrm{pmol} / \mu \mathrm{L}$ $\mathrm{A} \beta(1-40)$ and oleuropein in $1 \mathrm{mM}$ ammonium bicarbonate, $\mathrm{pH} 7.35$, incubated for $30 \mathrm{~min}$ at $37^{\circ} \mathrm{C}$.

\subsection{Enzymatic Cleavage of $A \beta(1-40)$ Prior to and after Complex Formation}

In the next step, we carried out an experiment for the identification of the $A \beta(1-40)$ amino acid sequence with the minimal amino acid residue length essential for oleuropein binding. The $A \beta(1-40)$ peptide was first proteolytically cleaved by trypsin and the mass spectrum, as per Figure 4, was acquired; then, the peptide mixture was allowed to interact with oleuropein, followed by the analysis at electrospray-triple quadrupole. The mass spectrum recorded is shown in Figure 5. 


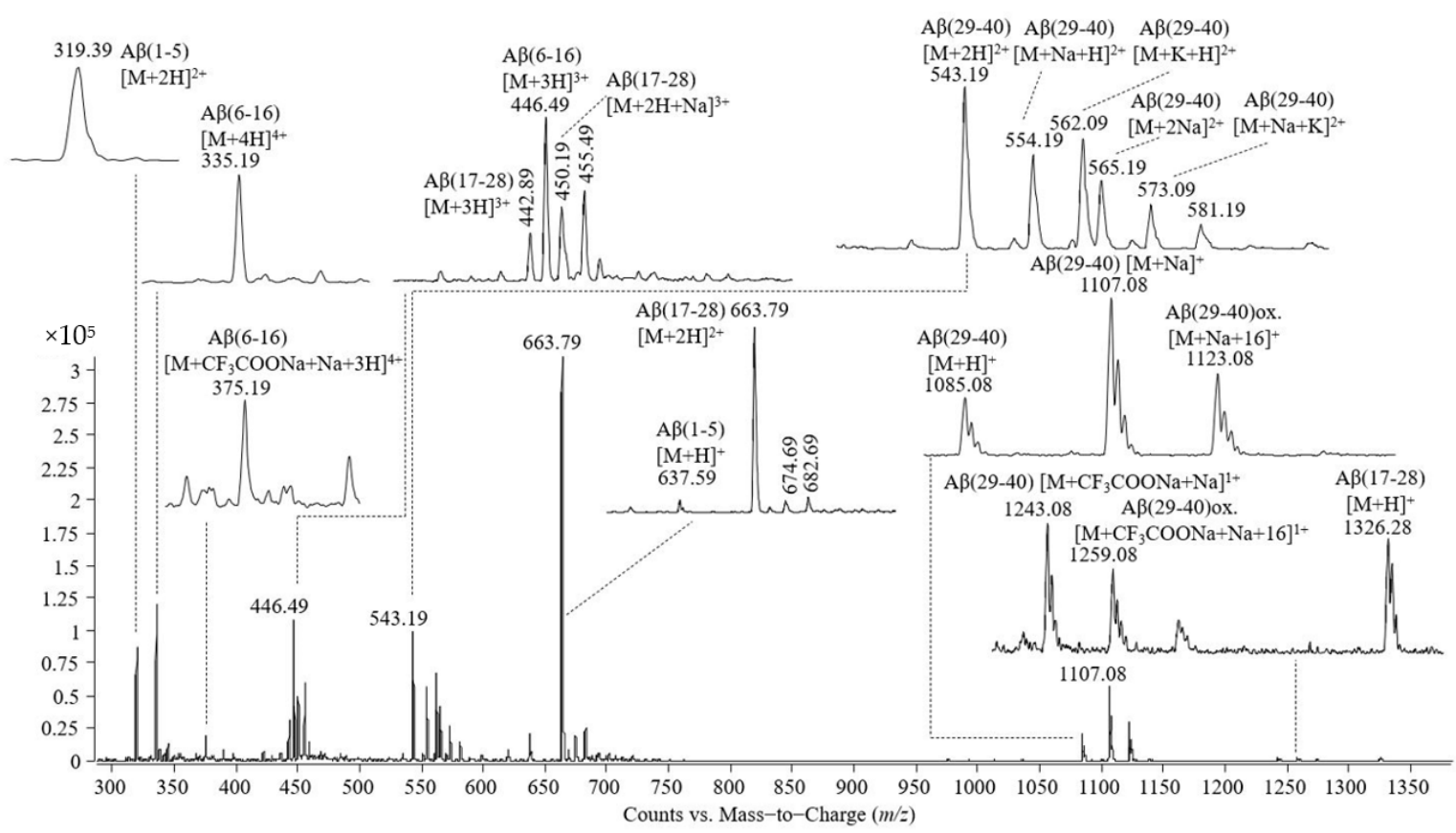

Figure 4. Mass spectrum obtained by ESI-triple quadrupole analysis of $A \beta(1-40)$, proteolitically cleaved by trypsin.

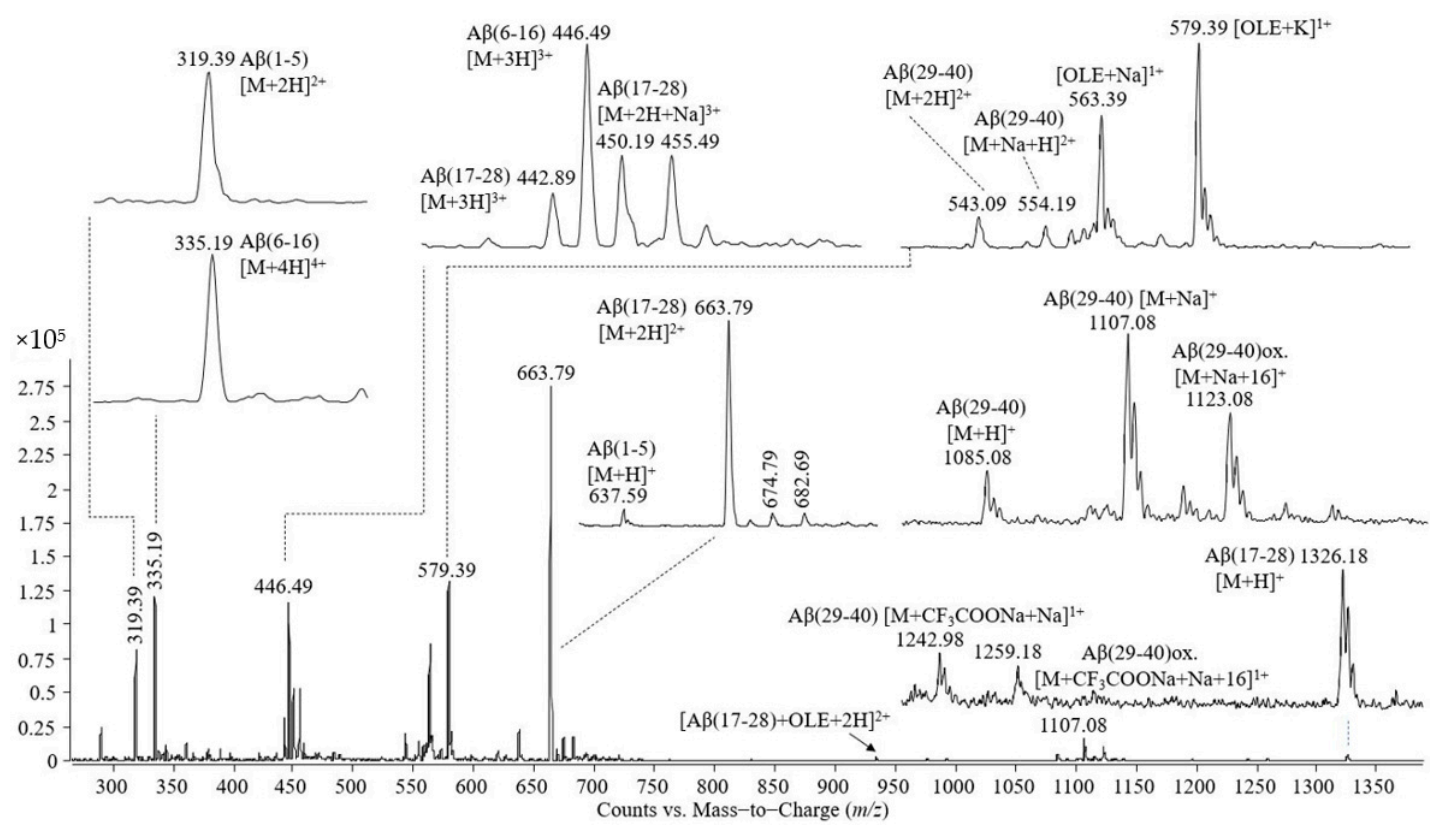

Figure 5. Mass spectrum obtained by ESI-triple quadrupole analysis of the proteolytic mixture resulting from A $\beta(1-40)$ cleavage by trypsin, incubated with oleuropein for $30 \mathrm{~min}$ at $37^{\circ} \mathrm{C}$.

The peaks observed in the mass spectrum shown in Figure 4 are as follows: (i) singleand double-protonated molecular ions of the peptide $A \beta(1-5)$ at $m / z$ values of 637.59 and 319.39; (ii) triple- and quadruple-protonated molecular ions of the peptide $A \beta(6-16)$ and the adduct with trifluoroacetate and sodium carrying four positive charges at $m / z 446.49$, 335.19 , and 375.19, respectively; (iii) single-, double-, and triple-protonated molecular ions of the peptide $A \beta(17-28)$ at $m / z 1326.28,663.79$, and 442.89 , respectively, and the adduct with one atom of sodium of the triple charged molecular ion of the peptide $\mathrm{A} \beta(17-28)$; (iv) a single-protonated molecular ion of the peptide $\mathrm{A} \beta(29-40)$ at $m / z 1085.08$, the adduct with sodium at $m / z 1107.08$, the adduct with sodium of the $\mathrm{A} \beta(29-40)$ oxidized at $m / z$ 1123.08 ; (v) a double-protonated molecular ion of the peptide $\mathrm{A} \beta(29-40)$ at $m / z 543.19$, the 
adducts of this peptide with one atom of sodium or potassium at $m / z 554.19$ and 562.09, the double-cationized molecular ion of $A \beta(29-40)$, namely, cationization with two atoms of sodium at $m / z 565.19$, cationization with one atom of sodium and one atom of potassium at $m / z$ 573.09; (vi) singly charged adducts with trifluoroacetate and sodium formed by $\mathrm{A} \beta(29-40)$ in non-modified and oxidized states.

In addition to these molecular ions, the mass spectrum presented in Figure 5 contains signals at $m / z 563.39$ and 579.39 , corresponding to the single charged adducts with sodium and potassium of oleuropein and the peak at $\mathrm{m} / \mathrm{z} 933.98$ corresponding to the noncovalent complex formed between the peptide $\mathrm{A} \beta(17-28)$ and oleuropein identified as a doubleprotonated molecular ion.

Figure 6 shows a detailed representation of the $m / z$ range $915-1005$. The spectrum placed in the upper part of the figure contains the signals present in the sample containing $\mathrm{A} \beta(1-40)$ cleaved by trypsin, while the spectrum placed in the lower part contains the signals of the tryptic mixture incubated with oleuropein.

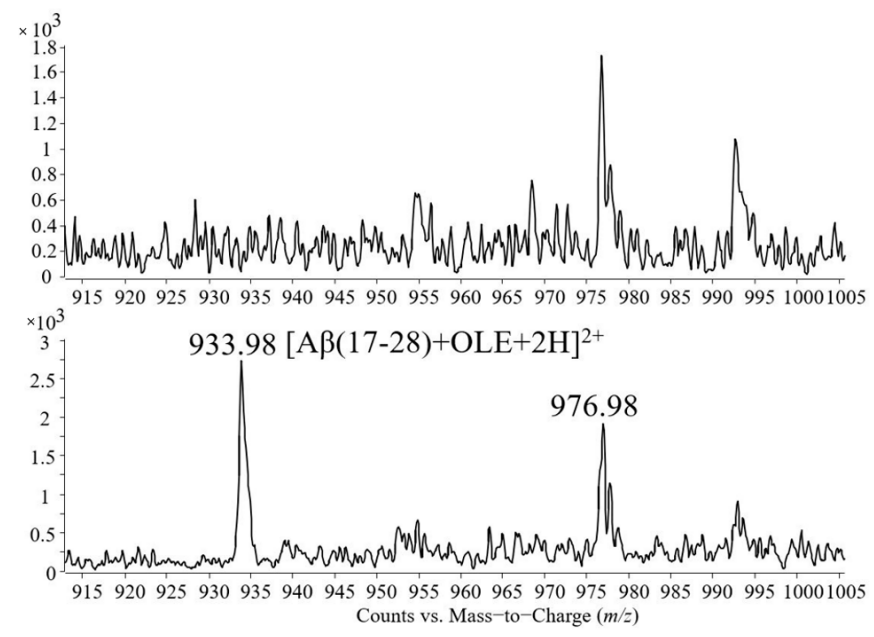

Figure 6. Detailed view of the $m / z$ range 915-1005 and comparison between the sample containing $\mathrm{A} \beta(1-40)$ tryptic mixture presented in Figure 4 and the sample containing $A \beta(17-28)$-oleuropein noncovalent complex presented in Figure 5.

In the next step, the $A \beta(1-40)$ peptide and oleuropein were allowed to form noncovalent complexes and, after confirming the formation of the complex via mass spectrometry, trypsin was added to the sample and allowed the chain of the peptide $A \beta(1-40)$ to be cleaved. The mass spectrum showed the same fragment $A \beta(17-28)$ binding to one molecule of oleuropein.

The identification of the binding site was further investigated using the proteolytic enzyme GluC. Proteolysis of A $\beta(1-40)$ by GluC prior to and after the formation of the noncovalent complex led to the observation of numerous molecular ions corresponding to proteolytic peptide fragments. However, the fractions that should contain the noncovalent complex between oleuropein and one of the proteolytic peptide fragments resulting from the cleavage of $\mathrm{A} \beta(1-40)$ peptide by GluC indicated the absence of a noncovalent complex.

Table 1 contains the assignments of the peaks observed in the mass spectra presented. 
Table 1. Assignment of the signals observed in the mass spectra.

\begin{tabular}{|c|c|c|c|c|c|}
\hline \multicolumn{2}{|c|}{ Molecular Ion } & \multirow{4}{*}{$\begin{array}{c}\text { Analyzed Mass } \\
\text { monoisotopic } \\
\text { monoisotopic } \\
\text { monoisotopic }\end{array}$} & \multirow{4}{*}{$\begin{array}{c}\text { Calculated } \mathrm{m} / z \\
541.19 \\
563.50 \\
579.61\end{array}$} & \multirow{4}{*}{$\begin{array}{c}\text { Experimental } \mathrm{m} / \mathrm{z} \\
- \\
563.39 \\
579.39\end{array}$} & \multirow{4}{*}{$\begin{array}{c}\Delta \mathrm{m}(\mathrm{Da}) \\
- \\
0.11 \\
0.22\end{array}$} \\
\hline & {$[\mathrm{OLE}+\mathrm{H}]^{+}$} & & & & \\
\hline Oleuropein monomer & {$[\mathrm{OLE}+\mathrm{Na}]^{+}$} & & & & \\
\hline & {$[\mathrm{OLE}+\mathrm{K}]^{+}$} & & & & \\
\hline \multirow{5}{*}{$\mathrm{A} \beta(1-40)$ Monomer } & {$[\mathrm{A} \beta+7 \mathrm{H}]^{7+}$} & average & 619.41 & 619.59 & -0.18 \\
\hline & {$[\mathrm{A} \beta+6 \mathrm{H}]^{6+}$} & average & 722.48 & 722.69 & -0.21 \\
\hline & {$[\mathrm{A} \beta+5 \mathrm{H}]^{5+}$} & average & 866.77 & 866.98 & -0.21 \\
\hline & {$[\mathrm{A} \beta+4 \mathrm{H}]^{4+}$} & average & 1083.21 & 1083.58 & -0.37 \\
\hline & {$[\mathrm{A} \beta+3 \mathrm{H}]^{3+}$} & average & 1443.95 & 1444.57 & -0.62 \\
\hline \multirow{6}{*}{ Noncovalent Complex } & {$[\mathrm{A} \beta+\mathrm{OLE}+6 \mathrm{H}]^{6+}$} & average & 812.56 & 812.78 & -0.22 \\
\hline & {$[\mathrm{A} \beta+\mathrm{OLE}+5 \mathrm{H}]^{5+}$} & average & 974.87 & 975.18 & -0.31 \\
\hline & {$[\mathrm{A} \beta+\mathrm{OLE}+4 \mathrm{H}]^{4+}$} & average & 1218.34 & 1218.78 & -0.44 \\
\hline & {$[\mathrm{A} \beta+2 \mathrm{OLE}+4 \mathrm{H}]^{4+}$} & average & 1353.47 & 1353.58 & -0.11 \\
\hline & {$[\mathrm{A} \beta+\mathrm{OLE}+3 \mathrm{H}]^{3+}$} & average & 1624.12 & 1624.47 & -0.35 \\
\hline & {$[\mathrm{A} \beta+2 \mathrm{OLE}+3 \mathrm{H}]^{3+}$} & average & 1804.30 & 1804.57 & -0.27 \\
\hline \multirow{2}{*}{ Tryptic Fragment $A \beta(1-5)$} & {$[\mathrm{M}+2 \mathrm{H}]^{2+}$} & average & 319.33 & 319.39 & -0.06 \\
\hline & {$[\mathrm{M}+\mathrm{H}]^{+}$} & monoisotopic & 637.29 & 637.59 & -0.30 \\
\hline \multirow{3}{*}{$\begin{array}{l}\text { Tryptic Fragment } \\
\text { A } \beta(6-16)\end{array}$} & {$[\mathrm{M}+4 \mathrm{H}]^{4+}$} & average & 335.10 & 335.19 & -0.09 \\
\hline & {$[\mathrm{M}+\mathrm{CF} 3 \mathrm{COONa}+\mathrm{Na}+3 \mathrm{H}]^{4+}$} & average & 374.59 & 375.19 & -0.60 \\
\hline & {$[\mathrm{M}+3 \mathrm{H}]^{3+}$} & average & 446.46 & 446.49 & -0.03 \\
\hline \multirow[t]{4}{*}{$\begin{array}{l}\text { Tryptic Fragment } \\
\text { A } \beta(17-28)\end{array}$} & {$[\mathrm{M}+3 \mathrm{H}]^{3+}$} & average & 442.83 & 442.89 & -0.06 \\
\hline & {$[\mathrm{M}+2 \mathrm{H}+\mathrm{Na}]^{3+}$} & average & 450.15 & 450.19 & -0.04 \\
\hline & {$[\mathrm{M}+2 \mathrm{H}]^{2+}$} & average & 663.74 & 663.79 & -0.05 \\
\hline & {$[\mathrm{M}+\mathrm{H}]^{+}$} & monoisotopic & 1325.67 & 1326.28 & -0.61 \\
\hline \multirow[t]{10}{*}{$\begin{array}{l}\text { Tryptic Fragment } \\
\text { A } \beta(29-40)\end{array}$} & {$[\mathrm{M}+2 \mathrm{H}]^{2+}$} & average & 543.69 & 543.19 & 0.50 \\
\hline & {$[\mathrm{M}+\mathrm{Na}+\mathrm{H}]^{2+}$} & average & 554.68 & 554.19 & 0.49 \\
\hline & {$[\mathrm{M}+\mathrm{K}+\mathrm{H}]^{2+}$} & average & 562.73 & 562.09 & 0.64 \\
\hline & {$[\mathrm{M}+2 \mathrm{Na}]^{2+}$} & average & 565.67 & 565.19 & 0.48 \\
\hline & {$[\mathrm{M}+\mathrm{Na}+\mathrm{K}]^{2+}$} & average & 573.72 & 573.09 & 0.63 \\
\hline & {$[\mathrm{M}+\mathrm{H}]^{+}$} & monoisotopic & 1085.63 & 1085.08 & 0.55 \\
\hline & {$[\mathrm{M}+\mathrm{Na}]^{+}$} & monoisotopic & 1107.62 & 1107.08 & 0.54 \\
\hline & {$[\mathrm{M}+\mathrm{Na}+16]^{+}$} & monoisotopic & 1123.61 & 1123.08 & 0.53 \\
\hline & {$[\mathrm{M}+\mathrm{CF} 3 \mathrm{COONa}+\mathrm{Na}]^{+}$} & monoisotopic & 1243.59 & 1243.08 & 0.51 \\
\hline & {$[\mathrm{M}+\mathrm{CF} 3 \mathrm{COONa}+\mathrm{Na}+16]^{+}$} & monoisotopic & 1259.59 & 1259.08 & 0.51 \\
\hline $\begin{array}{l}\text { A } \beta(17-28) \text {-Oleuropein } \\
\text { Noncovalent Complex }\end{array}$ & {$[\mathrm{A} \beta(17-28)+\mathrm{OLE}+2 \mathrm{H}]^{2+}$} & average & 934.00 & 933.98 & 0.02 \\
\hline
\end{tabular}

\section{Materials and Methods}

\subsection{Materials}

$\mathrm{A} \beta(1-40)$ peptide with an amidated carboxyl-terminal end, prepared as trifluoroacetate salt, was purchased from Bachem AG, Bubendorf, Switzerland (H-7664.1000). Oleuropein, 1,1,1,3,3,3-hexafluoro-2-propanol (HFIP) and ammonium bicarbonate were purchased from Sigma Aldrich, Saint Louis, MO, USA. Ammonium acetate was purchased from Honeywell Speciality Chemicals Seelze $\mathrm{GmbH}$, Seelze, Germany. Acetonitrile and water (HPLC purity) were purchased from LabScan analytical sciences, Gliwice, Poland. Formic acid was purchased from Merck, Darmstadt, Germany, and acetic acid was purchased from Lachner, Czech Republik. Double-distilled water was produced by an Autostill $^{\mathrm{TM}}$ apparatus distributed by Jencons Scientific Ltd, Leighton Buzzard, England.

\subsection{Preparation of Stock Solutions of $A \beta(1-40)$ and Oleuropein}

The vial containing lyophilized powder $\mathrm{A} \beta(1-40)$ peptide was stored upon receiving shipment until use in the freezer at $-24^{\circ} \mathrm{C}$. For the preparation of $\mathrm{A} \beta(1-40)$ stock solution, the tube was first allowed to reach room temperature. To ensure the location at the bottom of the vial of the entire amount of peptide $(1 \mathrm{mg})$, the vial was centrifuged for $30 \mathrm{~s}$ at $3000 \mathrm{rpm}$. An amount of $1 \mathrm{mg}$ of $\mathrm{A} \beta(1-40)$ peptide was solubilized in $200 \mu \mathrm{L}$ of $100 \%$ HFIP 
and the vial was agitated using a vortex 3 times for $30 \mathrm{~s}$, centrifuged for $30 \mathrm{~s}$ at $3000 \mathrm{rpm}$, and the solution was transferred into a Protein LoBind tube. The remaining A $\beta(1-40)$ was washed 4 times with $200 \mu \mathrm{L} \mathrm{100 \%} \mathrm{HFIP,} \mathrm{repeating} \mathrm{the} \mathrm{agitating} \mathrm{and} \mathrm{centrifugation} \mathrm{steps,}$ and all five fractions were mixed. The tube was spun for $30 \mathrm{~min}$ at $700 \mathrm{rpm}$ and $23{ }^{\circ} \mathrm{C}$. The resulting solution, having the final concentration $1 \mathrm{mg} / \mathrm{mL}$ of $\mathrm{A} \beta(1-40)$, was stored at $-24{ }^{\circ} \mathrm{C}$. Prior to use, the tube containing $\mathrm{A} \beta(1-40)$ stock solution was allowed to reach room temperature.

Upon receiving the shipment, the vial containing $10 \mathrm{mg}$ oleuropein was placed at $2{ }^{\circ} \mathrm{C}$ and stored until the preparation of the stock solution. Prior to use, the oleuropein was solubilized to a final concentration of $1 \mathrm{mg} / \mathrm{mL}$ in a solution containing $20 \%$ acetonitrile and $80 \%$ double-distilled water. The resulting solution was aliquoted in tubes containing $1 \mathrm{~mL}$ of oleuropein solution and placed at $-24{ }^{\circ} \mathrm{C}$ for long-term storage, except for one aliquot placed at $2{ }^{\circ} \mathrm{C}$ for immediate and short-term use.

\subsection{Complex Formation at $\mathrm{pH} 3$}

An amount of $64.9 \mu \mathrm{L}$ of $\mathrm{A} \beta(1-40)$ stock solution was pipetted in a $1.5 \mathrm{~mL}$ Protein LoBind tube. The tube was agitated with the lid open at $600 \mathrm{rpm}$ and at $24{ }^{\circ} \mathrm{C}$ for $2 \mathrm{~h}$ in an Eppendorf thermomixer F1.5. $150 \mu \mathrm{L}$ of bi-distilled water were added to the dried film of $A \beta(1-40)$ peptide located at the bottom of the tube. The sample was agitated in an Eppendorf thermomixer at $600 \mathrm{rpm}$ and $24^{\circ} \mathrm{C}$ for $5 \mathrm{~min}$ and mixed with $150 \mu \mathrm{L}$ of $100 \mathrm{pmol} / \mu \mathrm{L}$ oleuropein solution prepared by diluting oleuropein stock solution with $1 \mathrm{mM}$ ammonium acetate containing $0.5 \%$ acetic acid.

\subsection{Complex Formation in Ammonium Acetate at Different $p H$ Values}

An amount of $10 \mu \mathrm{L}$ of $\mathrm{A} \beta(1-40)$ stock solution was pipetted in each of four $1.5 \mathrm{~mL}$ Protein LoBind tubes and the HFIP was allowed to evaporate from the sample by agitating the tubes with the lids open at $600 \mathrm{rpm}$ and $24{ }^{\circ} \mathrm{C}$ for two hours. Four solutions of $0.5 \mathrm{mM}$ ammonium acetate with $\mathrm{pH}$ values of $4.4,5.3,6.2$, and 7.4 were prepared by diluting a $10 \mathrm{mM}$ stock solution of ammonium acetate and adjusting the $\mathrm{pH}$ with $10 \%$ acetic acid. Further, four solutions of $0.473 \mathrm{mM}$ ammonium acetate containing $100 \mathrm{pmol} / \mu \mathrm{L}$ oleuropein were obtained, from which $46 \mu \mathrm{L}$ were added to the four vials containing $10 \mu \mathrm{g}$ of dried amyloid beta (1-40) peptide. The samples were stirred for $30 \mathrm{~s}$ using a vortex and $4.5 \mathrm{~min}$ using a thermomixer at $1500 \mathrm{rpm}$ and were incubated at room temperature for two hours while spinning at $600 \mathrm{rpm}$. At $30 \mathrm{~min}$ and two hours, the samples were analyzed using the LC-MS system. The experiments were repeated, maintaining constant the concentration of $\mathrm{A} \beta(1-40)$ peptide and modifying oleuropein concentration for obtaining a molar ratio of $1: 1,1: 0.5$, and $1: 0.25$.

\subsection{Complex Formation in Ammonium Bicarbonate at Neutral $p H$}

An amount of $10 \mu \mathrm{L}$ of oleuropein stock solution was diluted with $360 \mu \mathrm{L}$ of $0.5 \mathrm{mM}$ ammonium bicarbonate and, respectively, $360 \mu \mathrm{L}$ of $1 \mathrm{mM}$ ammonium bicarbonate. In total, $46.2 \mu \mathrm{L}$ of each of these solutions was added separately to two Protein LoBind tubes containing $10 \mu \mathrm{g}$ of $\mathrm{A} \beta(1-40)$. The samples were agitated for $30 \mathrm{~s}$ using a vortex and $4.5 \mathrm{~min}$ using a thermomixer at $1500 \mathrm{rpm}$ and were incubated at room temperature for two hours while agitating at $600 \mathrm{rpm}$. After $30 \mathrm{~min}$ and after two hours of incubation, the samples were analyzed using the LC-MS system.

3.6. Identification of the Binding Sequence of $A \beta(1-40)$ by Proteolytic Cleavage of $A \beta(1-40)$ Prior to Complex Formation

An amount of $20 \mu \mathrm{L}$ of beta-amyloid (1-40) stock solution was introduced into a $1.5 \mathrm{~mL}$ Protein LoBind vial and the sample was agitated for $75 \mathrm{~min}$ with the lid open at room temperature and $600 \mathrm{rpm}$. In total, $92.4 \mu \mathrm{L}$ of $1 \mathrm{mM}$ ammonium bicarbonate, $\mathrm{pH}$ 7.35, was added and the vial was agitated for $30 \mathrm{~min}$ at $37^{\circ} \mathrm{C}$. Then, $1 \mu \mathrm{L}$ of a $1 \mu \mathrm{g} / \mu \mathrm{L}$ stock solution of trypsin solubilized in $50 \mathrm{mM}$ acetic acid was added. The sample was agitated for $2 \mathrm{~h}$ at $37^{\circ} \mathrm{C}$ and $600 \mathrm{rpm}$ and $20 \mu \mathrm{L}$ was removed.A volume of $10 \mu \mathrm{L}$ was analyzed at 
the electrospray-triple quadrupole. The remaining $72.4 \mu \mathrm{L}$ of the sample was mixed with $2.5 \mu \mathrm{L}$ of oleuropein stock solution and the vial was incubated for $18 \mathrm{~h}$ at $37^{\circ} \mathrm{C}$. At $30 \mathrm{~min}$, two hours, and $18 \mathrm{~h}, 20 \mu \mathrm{L}$ of the sample was removed and $10 \mu \mathrm{L}$ was analyzed using the mass spectrometer.

\subsection{Identification of the Binding Sequence of $A \beta(1-40)$ by Proteolytic Cleavage of $A \beta(1-40)$ after Complex Formation}

$\mathrm{A} \beta(1-40)$ was incubated for $30 \mathrm{~min}$ with oleuropein in $1 \mathrm{mM}$ ammonium bicarbonate, $\mathrm{pH} 7.35$, with both substances at a concentration of $50 \mathrm{pmol} / \mu \mathrm{L}$. The formation of the A $\beta(1-40)$-oleuropein complex was verified by analyzing $10 \mu \mathrm{L}$ of the mixture. Due to the observation of noncovalent complexes, the sample was further mixed with trypsin for two hours at $37^{\circ} \mathrm{C}$ and $10 \mu \mathrm{L}$ was injected into the mass spectrometer.

\subsection{Sample Analysis by LC-ESI-Triple Quadrupole Mass Spectrometer}

The sample was injected directly into the 6410 electrospray-triple quadrupole mass spectrometer (Agilent Scientific) using an Agilent 1200 high performance liquid chromatograph by removing the chromatography column and connecting the tubing in the chromatography column compartment using a stainless-steel union. The solvents employed at the liquid chromatograph were solvent $\mathrm{A}$, containing $5 \%$ acetonitrile and $0.1 \%$ formic acid in water, and solvent $\mathrm{B}$, containing $80 \%$ acetonitrile and $0.1 \%$ formic acid in water. Solvents $A$ and $B$ were mixed in the mixing chamber in the ratio of $6.7 \%$ solvent $B$ and $93.3 \%$ solvent $\mathrm{A}$. The resulting solution contained $10 \%$ acetonitrile and $0.1 \%$ formic acid in water. The volume of sample injected was $10 \mu \mathrm{L}$ and the flow rate was $0.05 \mathrm{~mL} / \mathrm{min}$.

The electrospray-triple quadrupole mass spectrometer was operated in positive mode. MS2 scans were carried out in the mass range of $m / z$ 100-2000. Source conditions were: nebulizer pressure $-35 \mathrm{psi}$, drying gas temperature $-325^{\circ} \mathrm{C}$, capillary voltage $-3850 \mathrm{~V}$.

\subsection{Data Analysis}

The $m / z$ values of the signals observed in the mass spectra, corresponding to intact molecules of oleuropein and beta-amyloid (1-40) peptide and to the cleavage peptide fragments resulting from the digestion of beta-amyloid (1-40) peptide by trypsin and endoprotease GluC, were compared to the $m / z$ values calculated using an Excel spreadsheet prepared by the authors using the monoisotopic and average atomic masses of the chemical elements occurring in the chemical compounds present in the samples analyzed.

\section{Conclusions}

The modification of the sample pretreatment introduced in the method for the observation of beta-amyloid-oleuropein noncovalent complex at $\mathrm{pH} 3$, published previously by Bazoti et al., allowed the formation of a noncovalent complex. Furthermore, by increasing the $\mathrm{pH}$ to 7.35 , the noncovalent complex was identified in ammonium acetate and ammonium bicarbonate. Proteolytic cleavage by trypsin carried out in ammonium bicarbonate led to the identification of beta-amyloid (17-28) as the minimal amino acid sequence involved in noncovalent complex formation. The fragments beta-amyloid (12-22) and (23-40), resulting after a complete proteolytic cleavage by GluC of $A \beta(1-40)$ in ammonium bicarbonate, do not separately preserve the affinity for oleuropein.

Due to the higher tendency of the peptide $A \beta(1-42)$ to aggregate in comparison with $A \beta(1-40)$, further studies should include the verification of $A \beta(1-42)$-oleuropein noncovalent complex formation. The stability of each noncovalent complex in human serum should be investigated and might be separated by immunoaffinity capture followed by observation by mass spectrometry.

Author Contributions: Conceptualization, R.Ş.; methodology, R.Ş.; validation, R.Ş. and I.C.C.; investigation, R.Ş. and I.C.C.; resources, R.Ş.; writing-original draft preparation, R.Ş. and I.C.C.; writing-review and editing, R.Ş. and B.I.T.; supervision, B.I.T.; project administration, R.Ş.; funding acquisition, R.Ş. All authors have read and agreed to the published version of the manuscript. 
Funding: This research was funded by "Grigore T. Popa" University of Medicine and Pharmacy, grant number 27498/20.12.2018. The APC was funded by "Grigore T. Popa" University of Medicine and Pharmacy.

Institutional Review Board Statement: Not applicable.

Informed Consent Statement: Not applicable.

Conflicts of Interest: The authors declare no conflict of interest. The funders had no role in the design of the study; in the collection, analyses, or interpretation of data; in the writing of the manuscript, or in the decision to publish the results.

Sample Availability: Samples of the compounds are available from the authors.

\section{References}

1. Loo, J.A. Studying noncovalent protein complexes by electrospray ionization mass spectrometry. Mass Spectrom. Rev. 1997, 16, 1-23. [CrossRef]

2. Horneffer, V.; Strupat, K.; Hillenkamp, F. Localization of Noncovalent Complexes in MALDI-Preparations by CLSM. J. Am. Soc. Mass Spectrom. 2006, 17, 1599-1604. [CrossRef] [PubMed]

3. Ştefănescu, R.; Stanciu, G.D.; Luca, A.; Caba, I.C.; Tamba, B.I.; Mihai, C.T. Contributions of mass spectrometry to the identification of low molecular weight molecules able to reduce the toxicity of amyloid- $\beta$ peptide to cell cultures and transgenic mouse models of Alzheimer's disease. Molecules 2019, 24, 1167. [CrossRef] [PubMed]

4. Stefanescu, R.; Iacob, R.E.; Damoc, E.N.; Marquardt, A.; Amstalden, E.; Manea, M.; Perdivara, I.; Maftei, M.; Paraschiv, G.; Przybylski, M. Mass spectrometric approaches for elucidation of antigenantibody recognition structures in molecular immunology. Eur. J. Mass Spectrom. 2007, 13, 69-75. [CrossRef] [PubMed]

5. Tian, X.; Cecal, R.; McLaurin, J.A.; Manea, M.; Stefanescu, R.; Grau, S.; Harnasch, M.; Amir, S.; Ehrmann, M.; St George-Hyslop, P.; et al. Identification and structural characterisation of carboxy-terminal polypeptides and antibody epitopes of Alzheimer's amyloid precursor protein using high-resolution mass spectrometry. Eur. J. Mass Spectrom. 2005, 11, 547-555. [CrossRef] [PubMed]

6. Stefanescu, R.; Stanciu, G.D.; Luca, A.; Paduraru, L.; Tamba, B.I. Secondary metabolites from plants possessing inhibitory properties against beta-amyloid aggregation as revealed by thioflavin-t assay and correlations with investigations on transgenic mouse models of alzheimer's disease. Biomolecules 2020, 10, 870. [CrossRef] [PubMed]

7. Bazoti, F.N.; Bergquist, J.; Markides, K.E.; Tsarbopoulos, A. Noncovalent interaction between amyloid-beta-peptide (1-40) and oleuropein studied by electrospray ionization mass spectrometry. J. Am. Soc. Mass Spectrom. 2006, 17, 568-575. [CrossRef] [PubMed]

8. Bazoti, F.N.; Bergquist, J.; Markides, K.; Tsarbopoulos, A. Localization of the Noncovalent Binding Site between Amyloid- $\beta$ Peptide and Oleuropein Using Electrospray Ionization FT-ICR Mass Spectrometry. J. Am. Soc. Mass Spectrom. 2008, 19, $1078-1085$. [CrossRef] [PubMed]

9. Yoshiike, Y.; Tanemura, K.; Murayama, O.; Akagi, T.; Murayama, M.; Sato, S.; Sun, X.; Tanaka, N.; Takashima, A. New Insights on How Metals Disrupt Amyloid $\beta$-Aggregation and Their Effects on Amyloid- $\beta$ Cytotoxicity. J. Biol. Chem. 2001, 276, 32293-32299. [CrossRef]

10. Yateem, H.; Afaneh, P.; Al-Rimawi, F. Optimum Conditions for Oleuropein Extraction from Olive Leaves. Int. J. Appl. Sci. Technol. 2014, 4, 153-157. 